\title{
Flame atomic absorption spectrometric determination of multi element in apricot and soil samples after wet and microwave digestion method
}

\author{
Inci KAYGUSUZ ${ }^{1}$ (i), Mustafa TÜZEN ${ }^{1, *}$ (i) \\ ${ }^{I}$ Tokat Gaziosmanpasa University, Faculty of Science and Arts, Chemistry Department, 60250 Tokat, TURKEY
}

\begin{abstract}
Iron, copper, zinc, manganese, nickel, cobalt, lead, cadmium and chromium in various apricot and soil samples were determined by atomic absorption spectrometry in this study. Microwave digestion method and wet ashing method efficiency were compared for digestion of the samples. Recovery values were nearly found quantitative. The analysis results were evaluated. The accuracy of the digestion procedures was confirmed by analyzing Montana Soil and Apple Leaves certified reference materials. There are no important differences between digestion methods. The results were compared with literature values. Relative standard deviations were found below $10 \%$. Heavy metal levels in analyzed samples were not found toxic limits.
\end{abstract}

\author{
Article info \\ History: \\ Received: 16.11 .2020 \\ Accepted: 30.04 .2021 \\ Keywords: \\ Heavy metal, \\ Microwave digestion, \\ Wet Ashing \\ Apricot, \\ Soil, Atomic \\ absorption \\ spectrometry.
}

\section{Introduction}

The most important environmental pollution is sourced from heavy metals. Food contamination is now accepted as an indisputable fact all over the world. Toxic elements found naturally in foodstuffs are not generally harmful to human health [1]. Chemical contamination can be of natural, environmental and technological origin. Since food contamination is difficult to prevent and control, the consequences appear in a long time and can be even more effective in terms of health $[2,3]$. Apricot is a product that is consumed throughout the year in the form of fresh, dried and fruit juice. Apricot has positive effects on human health through organic and inorganic substances contains [4]. Heavy metals are passed to apricot from soil and its irrigation water. The other source of heavy metals is traffic [5].

Iron, copper, zinc, manganese and cobalt are known essential heavy metals, but nickel, lead, cadmium and chromium are toxic element for human, animal and environmental health. Essential elements can be also harmful effects when their high consumption [6]. So, it is very important for accurate and sensitive determination of heavy metal levels in food, soil and environmental samples. Digestion procedure is very important step before determination of heavy metals in solid matrix. Various digestion procedures such as dry ashing, wet ashing and microwave digestion are used for this aim. Dry ashing and wet ashing procedures are slow and time consumption but microwave digestion method is fast, clean and environmentally friendly [7, 8].

Various instrumental detection system such as inductively couple plasma mass spectrometry (ICPMS), inductively couple plasma optic emission spectrometry (ICP-OES), energy dispersive x-ray fluorescence spectrometry and atomic absorption spectrometry (AAS) have been used for the determination of traces heavy metal ions in food and environmental samples [9-12]. Atomic absorption spectrometry is the main instrument for the determination of heavy metals in food, soil and environmental samples because of its simplicity, low cost and sensitivity [13, 14]. According to our literature survey, multi element levels were not determined in apricot and soil samples collected from Malatya, Turkey after different digestion methods. It is aimed to determine the levels of traces heavy metals in apricot and soil samples and to evaluate them in terms of environment and human health. In this study the performance of wet ashing and microwave digestion methods were compared by using real apricot and soil samples. The accuracy of the digestion procedures was confirmed by analyzing Montana Soil and Apple Leaves certified reference materials. 


\section{Materials and Methods}

\subsection{Reagents}

Analytical reagent grade chemicals were used in this study. Double distilled deionized water (Milli-Q Millipore (Bedford, MA, USA) $18.2 \mathrm{M} \Omega \mathrm{cm}^{-1}$ ) was used for the dilutions of all solutions. All plastic and glassware were soaked with $\mathrm{HNO}_{3}(10 \%)$ and then rinsed with deionized water before use. $1000 \mathrm{mg} \mathrm{L}^{-1}$ stock solutions of the elements were prepared their salts purchased from Merck company (Darmstadt, Germany). Working solutions of elements were prepared daily from stock solution by using dilution procedure. NIST SRM 1515 Apple Leaves and NIST
SRM 2711 Montana Soil certified reference materials were used to check the accuracy of the method.

\subsection{Apparatus}

Perkin Elmer AAnalyst 700 model deuterium background corrected atomic absorption spectrometry (Norwalk, CT, USA) was used for the measurement of elements. Flame atomization was performed in airacetylene environment. Working conditions of element in FAAS were given in Table 1. Hollow cathode lamps were used. Milestone Ethos D model (Sorisole-Bg, Italy) closed system microwave oven (maximum temperature $300^{\circ} \mathrm{C}$, maximum pressure $1450 \mathrm{psi}$ ) was used to dissolve standard reference materials and apricot samples.

Table 1. Working conditions of element in FAAS

\begin{tabular}{ccccc}
\hline Element & $\begin{array}{c}\text { Acetylene } \\
(\mathrm{L} / \mathrm{min})\end{array}$ & $\begin{array}{c}\text { Air } \\
(\mathrm{L} / \mathrm{min})\end{array}$ & $\begin{array}{c}\text { Wavelengths } \\
(\mathrm{nm})\end{array}$ & $\begin{array}{c}\text { Slit wave } \\
(\mathrm{nm})\end{array}$ \\
\hline $\mathrm{Fe}$ & 2.0 & 17.0 & 248.3 & 0.2 \\
$\mathrm{Cu}$ & 2.0 & 17.0 & 324.8 & 0.7 \\
$\mathrm{Zn}$ & 2.0 & 17.0 & 213.9 & 0.7 \\
$\mathrm{Mn}$ & 2.0 & 17.0 & 279.5 & 0.2 \\
$\mathrm{Cd}$ & 2.0 & 17.0 & 326.1 & 0.2 \\
$\mathrm{Ni}$ & 2.0 & 17.0 & 341.5 & 0.2 \\
$\mathrm{Co}$ & 2.0 & 17.0 & 345.4 & 0.2 \\
$\mathrm{Cr}$ & 2.0 & 17.0 & 357.9 & 0.7 \\
$\mathrm{~Pb}$ & 2.0 & 17.0 & 283.3 & 0.7 \\
\hline
\end{tabular}

\subsection{Sampling}

In this study, apricot and soil samples collected from various regions of Malatya city, Turkey were used. The samples were dried in an oven at $105^{\circ} \mathrm{C}$ and ground into powder. The samples were then packaged and stored.

\subsection{Digestion procedures}

\subsubsection{Microwave digestion}

Apricot samples $(0.5 \mathrm{~g})$ and standard reference material (NIST SRM 1515 Apple Leaves) (0.25 g) were taken into microwave container and $6 \mathrm{~mL}$ of $65 \%$ $\mathrm{HNO}_{3}$ and $2 \mathrm{~mL}$ of $37 \% \mathrm{HCI}$ were added. Soil samples $(0.5 \mathrm{~g})$ and NIST SRM 2711 Montana Soil $(0.1 \mathrm{~g})$ were taken into the microwave container and $6 \mathrm{~mL}$ of $37 \%$ $\mathrm{HCl}, 2 \mathrm{~mL}$ of $65 \% \mathrm{HNO}_{3}, 0.5 \mathrm{~mL}$ of $40 \%$ HF were added. The samples were digested in microwave system. The following program was used in the digestion process; $4 \mathrm{~min}, 250 \mathrm{~W} ; 7 \mathrm{~min}, 400 \mathrm{~W} ; 10$ $\min , 550 \mathrm{~W}$; ventilation: $10 \mathrm{~min}$. The samples dissolved in the microwave system then particles filtered through the blue band filter paper. Then it was completed to $10 \mathrm{~mL}$ with distilled deionized water. A blank digest was also prepared.

\subsubsection{Wet digestion}

$1 \mathrm{~g}$ of apricot samples and $0.2 \mathrm{~g}$ of NIST SRM 1515 Apple Leaves were taken into a conical flask and $6 \mathrm{~mL}$ of $65 \% \mathrm{HNO}_{3}$ and $2 \mathrm{ml}$ of $37 \% \mathrm{HCI}$ were added. Soil samples $(0.5 \mathrm{~g})$ and NIST SRM 2711 Montana Soil $(0.1 \mathrm{~g})$ were taken into a conical flask and $6 \mathrm{~mL}$ of 37 $\% \mathrm{HCl}, 2 \mathrm{~mL}$ of $65 \% \mathrm{HNO}_{3}$ were added. The samples were put on the hot plate and heated $30 \mathrm{~min}$ in $150^{\circ} \mathrm{C}$ until dryness. This process was repeated two times. The samples were cooled and filtered by using blue band filter paper. The final volume was completed to $10 \mathrm{~mL}$ with deionized water. A blank digest was also prepared as the same way. 


\section{Results and Discussion}

Analytical characteristics such as correlation coefficient, linear range, regression equation and RSD values of trace elements in FAAS were given in Table
2. RSD values were found below $10 \%$. The comparison of the microwave and wet ashing digestion performance of trace elements by using NIST SRM 1515 Apple Leaves and NIST SRM 2711 Montana Soil were given in Table 3 and Table 4, respectively.

Table 2. Analytical characteristics

\begin{tabular}{ccccc}
\hline Element & $\begin{array}{c}\text { Correlation } \\
\text { coefficient }\end{array}$ & $\begin{array}{c}\text { Linear range } \\
\left(\mathrm{mg} \mathrm{L}^{-1}\right)\end{array}$ & Regression equation & $\mathrm{RSD}, \%$ \\
\hline $\mathrm{Co}$ & 0.9999 & $0.25-5.0$ & $\mathrm{~A}=0.0383 \mathrm{C}+0.0013$ & 5.5 \\
$\mathrm{~Pb}$ & 0.9999 & $0.5-10.0$ & $\mathrm{~A}=0.0048 \mathrm{C}+0.0005$ & 4.5 \\
$\mathrm{Ni}$ & 0.9996 & $0.25-5.0$ & $\mathrm{~A}=0.0219 \mathrm{C}+0.00002$ & 3.9 \\
$\mathrm{Cu}$ & 0.9999 & $0.25-5.0$ & $\mathrm{~A}=0.02667 \mathrm{C}-0.0006$ & 6.4 \\
$\mathrm{Fe}$ & 0.9996 & $0.25-5.0$ & $\mathrm{~A}=0.0202 \mathrm{C}+0.0036$ & 5.9 \\
$\mathrm{Cd}$ & 0.9995 & $0.02-2.0$ & $\mathrm{~A}=0.1405 \mathrm{C}+0.0076$ & 7.2 \\
$\mathrm{Cr}$ & 0.9998 & $0.50-10.0$ & $\mathrm{~A}=0.0245 \mathrm{C}+0.0011$ & 8.5 \\
$\mathrm{Mn}$ & 0.9995 & $0.10-3.0$ & $\mathrm{~A}=0.081 \mathrm{C}+0.0029$ & 9.0 \\
$\mathrm{Zn}$ & 0.9996 & $0.02-1.0$ & $\mathrm{~A}=0.2831 \mathrm{C}+0.0041$ & 10 \\
\hline
\end{tabular}

A: Absorbance, C: Concentration, RSD: Relative standard deviation

Table 3. Comparison of the digestion performance of trace elements using NIST SRM 1515 Apple Leaves, N=4

\begin{tabular}{|c|c|c|c|c|}
\hline Element & Certified value $(\mu \mathrm{g} / \mathrm{g})$ & Method & Observed value $(\mu \mathrm{g} / \mathrm{g})$ & Recovery (\%) \\
\hline \multirow[t]{2}{*}{$\mathrm{Co}$} & $(0.09)^{\mathrm{a}}$ & Microwave digestion & BDL & - \\
\hline & & Wet ashing & BDL & - \\
\hline \multirow[t]{2}{*}{$\mathrm{Pb}$} & 0.47 & Microwave digestion & $0.48 \pm 0.03$ & 102 \\
\hline & & Wet ashing & $0.45 \pm 0.03$ & 96 \\
\hline \multirow[t]{2}{*}{$\mathrm{Ni}$} & 0.91 & Microwave digestion & $0.90 \pm 0.05$ & 99 \\
\hline & & Wet ashing & $0.86 \pm 0.08$ & 95 \\
\hline \multirow[t]{2}{*}{$\mathrm{Cu}$} & 5.64 & Microwave digestion & $5.55 \pm 0.10$ & 98 \\
\hline & & Wet ashing & $5.36 \pm 0.30$ & 95 \\
\hline \multirow[t]{2}{*}{$\mathrm{Fe}$} & (83) & Microwave digestion & $80.7 \pm 2.5$ & 97 \\
\hline & & Wet ashing & $78.9 \pm 4.7$ & 95 \\
\hline \multirow[t]{2}{*}{$\mathrm{Cd}$} & 0.013 & Microwave digestion & BDL & - \\
\hline & & Wet ashing & BDL & - \\
\hline \multirow[t]{2}{*}{$\mathrm{Cr}$} & $(0.3)$ & Microwave digestion & $0.31 \pm 0.03$ & 103 \\
\hline & & Wet ashing & $0.28 \pm 0.03$ & 93 \\
\hline \multirow[t]{2}{*}{$\mathrm{Mn}$} & 54 & Microwave digestion & $53.1 \pm 3.1$ & 98 \\
\hline & & Wet ashing & $51.8 \pm 4.2$ & 96 \\
\hline \multirow[t]{2}{*}{$\mathrm{Zn}$} & 12.5 & Microwave digestion & $12.2 \pm 0.9$ & 98 \\
\hline & & Wet ashing & $11.9 \pm 0.8$ & 95 \\
\hline
\end{tabular}

${ }^{a}$ not certified, BDL: Below detection limit 
Table 4. Comparison of the digestion performance of trace elements using NIST SRM 2711 Montana Soil, N=4

\begin{tabular}{|c|c|c|c|c|}
\hline Element & Certified value $(\mu \mathrm{g} / \mathrm{g})$ & Method & $\begin{array}{l}\text { Observed value } \\
\qquad(\mu \mathrm{g} / \mathrm{g})\end{array}$ & Recovery (\%) \\
\hline \multirow[t]{2}{*}{$\mathrm{Co}$} & $(10)^{\mathrm{a}}$ & Microwave digestion & $9.8 \pm 0.4$ & 98 \\
\hline & & Wet ashing & $9.5 \pm 0.7$ & 95 \\
\hline \multirow[t]{2}{*}{$\mathrm{Pb}$} & 1162 & Microwave digestion & $1127 \pm 30$ & 97 \\
\hline & & Wet ashing & $1103 \pm 75$ & 95 \\
\hline \multirow[t]{2}{*}{$\mathrm{Ni}$} & 20.6 & Microwave digestion & $20.1 \pm 1.5$ & 98 \\
\hline & & Wet ashing & $19.6 \pm 1.7$ & 95 \\
\hline \multirow[t]{2}{*}{$\mathrm{Cu}$} & 114 & Microwave digestion & $110 \pm 5$ & 96 \\
\hline & & Wet ashing & $108 \pm 8$ & 95 \\
\hline \multirow[t]{2}{*}{$\mathrm{Fe}$} & 28900 & Microwave digestion & $28033 \pm 250$ & 97 \\
\hline & & Wet ashing & $27455 \pm 530$ & 95 \\
\hline \multirow[t]{2}{*}{$\mathrm{Cd}$} & 41.7 & Microwave digestion & $41.4 \pm 2.6$ & 99 \\
\hline & & Wet ashing & $40.1 \pm 3.1$ & 96 \\
\hline \multirow[t]{2}{*}{$\mathrm{Cr}$} & (47) & Microwave digestion & $45.4 \pm 1.9$ & 97 \\
\hline & & Wet ashing & $45.1 \pm 2.7$ & 96 \\
\hline \multirow[t]{2}{*}{$\mathrm{Mn}$} & 638 & Microwave digestion & $625 \pm 20$ & 98 \\
\hline & & Wet ashing & $606 \pm 45$ & 95 \\
\hline \multirow[t]{2}{*}{$\mathrm{Zn}$} & 350.4 & Microwave digestion & $352 \pm 23$ & 101 \\
\hline & & Wet ashing & $336 \pm 30$ & 96 \\
\hline
\end{tabular}

${ }^{a}$ not certified

The recovery of trace element in NIST SRM 1515 Apple Leaves were found in the range of $93-95 \%$ for wet ashing, 97-103\% for microwave digestion. The recovery of trace element in NIST SRM 2711 Montana Soil were found in the range of $95-96 \%$ for wet ashing, 96-101 \% for microwave digestion, respectively. Recovery values were nearly quantitative for analyzed iron, copper, zinc, manganese, nickel, cobalt, lead, cadmium and chromium ions. The results were close to each other for wet and microwave digestion methods. Microwave digestion method has been applied in real samples because the recoveries in microwave is higher, the analysis time is shorter and the risk of contamination is less. HF was not used in wet ashing method because of its can be damage to glassware. HF is important for solubilization of silicates in soil samples. But, the recovery values were found quantitative without HF.
Optimized method was applied to real apricot and soil samples collected from different region of Malatya city, Turkey. Soil samples were collected from near and far from traffic areas. The results are given in Table 5. Trace element contents of analyzed soil samples collected near the traffic areas were found higher than other samples. The highest and lowest values of the samples were found in iron and cadmium. Lead, chromium and cadmium concentrations in some apricot samples were found below detection limit of FAAS. Cadmium levels were also found below detection limit in some soil samples. Heavy metal levels in analyzed samples were in agreement with literature values [15-22]. The maximum iron, lead and cadmium levels permitted for food samples is $15 \mathrm{mg}$ $\mathrm{kg}^{-1}, 0.1 \mathrm{mg} \mathrm{kg}^{-1}$ and $0.05 \mathrm{mg} \mathrm{kg}^{-1}$, respectively according to Turkish Food Codex [23]. Heavy metal levels in analyzed samples were not found toxic limits. 
Table 5. Trace element contents of apricot and soil samples collected from Malatya, Turkey ( $\mu \mathrm{g} / \mathrm{g}), \mathrm{N}=3$

\begin{tabular}{|c|c|c|c|c|c|c|c|c|c|}
\hline Sample & $\mathrm{Pb}$ & $\mathrm{Cd}$ & $\mathrm{Fe}$ & $\mathrm{Cu}$ & $\mathrm{Zn}$ & $\mathrm{Cr}$ & $\mathrm{Ni}$ & $\mathrm{Co}$ & $\mathrm{Mn}$ \\
\hline Apricot 1 & BDL & BDL & $8.93 \pm 0.50$ & $3.97 \pm 0.10$ & $3.38 \pm 0.14$ & BDL & $4.05 \pm 0.10$ & $1.52 \pm 0.10$ & $0.67 \pm 0.05$ \\
\hline Apricot 2 & BDL & BDL & $5.91 \pm 0.32$ & $2.50 \pm 0.15$ & $0.58 \pm 0.03$ & BDL & $7.07 \pm 0.27$ & $2.92 \pm 0.20$ & $0.81 \pm 0.06$ \\
\hline Apricot 3 & BDL & $0.33 \pm 0.01$ & $14.6 \pm 1.1$ & $3.23 \pm 0.20$ & $1.47 \pm 0.12$ & BDL & $4.48 \pm 0.15$ & $2.57 \pm 0.11$ & $1.10 \pm 0.10$ \\
\hline Apricot 4 & $\mathrm{BDL}$ & $\mathrm{BDL}$ & $8.94 \pm 0.30$ & $3.73 \pm 0.12$ & $2.36 \pm 0.16$ & BDL & $2.33 \pm 0.12$ & $1.87 \pm 0.13$ & $1.25 \pm 0.11$ \\
\hline $\begin{array}{c}\text { Region } 1 \\
\text { (near } \\
\text { traffic) } \\
\text { Soil }\end{array}$ & $24.6 \pm 1.5$ & $0.49 \pm 0.02$ & $4340 \pm 50$ & $54.6 \pm 2.3$ & $162 \pm 20$ & $39.7 \pm 2.5$ & $56.6 \pm 3.8$ & $12.9 \pm 1.1$ & $179 \pm 7$ \\
\hline $\begin{array}{c}\text { Region } 1 \\
\text { (far traffic) } \\
\text { Soil }\end{array}$ & $21.2 \pm 1.1$ & $0.67 \pm 0.03$ & $4192 \pm 25$ & $37.8 \pm 2.7$ & $26.2 \pm 1.7$ & $37.5 \pm 1.5$ & $44.3 \pm 3.1$ & $14.2 \pm 0.9$ & $199 \pm 10$ \\
\hline $\begin{array}{c}\text { Region } 2 \\
\text { (near } \\
\text { traffic) } \\
\text { Soil }\end{array}$ & $24.5 \pm 1.3$ & $0.84 \pm 0.05$ & $5799 \pm 30$ & $39.7 \pm 2.1$ & $23.5 \pm 1.9$ & $38.5 \pm 2.4$ & $52.1 \pm 2.8$ & $12.8 \pm 0.8$ & $233 \pm 16$ \\
\hline $\begin{array}{c}\text { Region } 2 \\
\text { (far traffic) } \\
\text { Soil }\end{array}$ & $27.8 \pm 1.5$ & $0.67 \pm 0.04$ & $6266 \pm 55$ & $51.9 \pm 1.9$ & $27.8 \pm 2.2$ & $55.8 \pm 3.6$ & $62.2 \pm 4.8$ & $16.3 \pm 1.2$ & $309 \pm 21$ \\
\hline $\begin{array}{c}\text { Region } 3 \\
\text { (near } \\
\text { traffic) } \\
\text { Soil }\end{array}$ & $17.9 \pm 0.9$ & BDL & $17377 \pm 76$ & $16.7 \pm 0.8$ & $29.0 \pm 2.1$ & $56.8 \pm 2.8$ & $57.3 \pm 3.5$ & $29.7 \pm 1.9$ & $671 \pm 32$ \\
\hline $\begin{array}{c}\text { Region } 3 \\
\text { (far traffic) } \\
\text { Soil }\end{array}$ & $17.9 \pm 0.8$ & BDL & $13410 \pm 80$ & $17.2 \pm 0.9$ & $20.3 \pm 1.5$ & $50.7 \pm 2.7$ & $49.4 \pm 2.6$ & $24.0 \pm 1.4$ & $580 \pm 27$ \\
\hline
\end{tabular}

BDL: Below detection limit

\section{Conclusions}

The performance of wet ashing and microwave digestion methods were compared for the digestion of apricot and soil samples collected different regions according to near and far traffic area from Malatya, Turkey. Recovery values were tested by using certified reference materials. There are no important differences between digestion methods. RSD values in microwave digestion method were found lower than wet ashing method. Trace element contents of soil samples collected near the traffic areas were found higher than other samples. Microwave digestion method has been used in real apricot and soil samples because of its higher recoveries and shorter digestion time. Microwave digestion has also some advantages with respect to the risk of contamination, reduce to some volatile species and environmental protection. Food samples collected from industrial and traffic areas should be more analyzed with respect to toxic heavy metals. Contaminated food samples should not be consumption in all time.

\section{Acknowledgements}

The authors would like to thanks Dr. Demirhan Citak and Dr. Ozgur Dogan Uluozlu for their help in experimental studies. The authors would like to Tokat Gaziosmanpasa University for master thesis of İnci Kaygusuz.

\section{Conflict of interest}

The authors declare that they have no conflict of interests 


\section{References}

[1] El-Kady, A.A., Abdel-Wahhab, M.A., Occurrence of trace metals in foodstuffs and their health impact, Trends in Food Science \& Technology, 75 (2018) 36-45.

[2] Dar, M.I. Green, I.D., Khan, F.A., Trace metal contamination: Transfer and fate in food chains of terrestrial invertebrates, Food Webs, 20 (2019) $\mathrm{e} 00116$

[3] Gallo, M., Ferrara, L., Calogero, A., Montesano, D., Navigli, D., Relationships between food and diseases: What to know to ensure food safety, Food Research International, 137 (2020) 109414.

[4] Munzuroglu, O., Karatas, F., Geckil, H., The vitamin and selenium contents of apricot fruit of different varieties cultivated in different geographical regions, Food Chemistry, 83 (2003) 205-212.

[5] Davarynejad, G. H., Vatandoost, S., Soltész, M., Nyéki, J., Szabó, Z., Nagy, P.T., Hazardous element content and consumption risk of 9 apricot cultivars, International Journal of Horticultural Science, 16 (4) (2010) 61-65.

[6] Briffa, J., Sinagra, E., Blundell, R., Heavy metal pollution in the environment and their toxicological effects on humans, Heliyon, 6 (2020) e04691.

[7] Chavez E., He Z. L., Stoffella P. J., Mylavarapu R. S., Li Y. C., Moyano B., Baligar V. C., Concentration of cadmium in cacao beans and its relationship with soil cadmium in southern Ecuador, Sci. Total Environ., 533 (2015) 205-214.

[8] Tuzen M., Soylak M., Evaluation of trace element contents in canned foods marketed from Turkey. Food Chem., 102 (2007) 1089-1095.

[9] Suo, L., Dong, X., Gao, X., Xu, J., Huang, Z., Ye, J., Lua, X., Silica-coated magnetic graphene oxide nanocomposite based magnetic solid phase extraction of trace amounts of heavy metals in water samples prior to determination by inductively coupled plasma mass spectrometry, Microchemical Journal, 149 (2019) 104039.

[10] Altundag, H., \& Tuzen, M. (2011). Comparison of dry, wet and microwave digestion methods for the multi element determination in some dried fruit samples by ICP-OES. Food and Chemical Toxicology, 49 (2011) 2800-2807.

[11] de Almeida, O.N., Luzardo, F.H.M., Amorim, F.A.C., Velasco, F.G., González, L.N., Use of fiberglass support in the application of dried-spot technique with dispersion liquid-liquid microextraction for the determination of $\mathrm{Co}, \mathrm{Cr}$, $\mathrm{Cu}, \mathrm{Ni}$ and $\mathrm{Pb}$ by Energy Dispersive X-Ray Fluorescence Spectrometry, Spectrochimica Acta Part B, 150 (2018) 92-98.

[12] Zhao, X., Song, N., Zhou, W. \& Jia, Q., Preconcentration procedures for the determination of chromium using atomic spectrometric techniques: A review. Cent. Eur. J. Chem., 10 (2012) 927-937.

[13] Mykhailo M. V., Copper, zinc, and cadmium in various fractions of soil and fungi in a Swedish forest, J. Environ. Sci. Heal. A, 48(8) (2013) 980987.

[14] Squadrone S., Brizio P., Chiaravalle E., Abete M. C., Sperm whales (Physeter macrocephalus), found stranded along the Adriatic coast (Southern Italy, Mediterranean Sea), as bioindicators of essential and non-essential trace elements in the environment, Ecol. Indic., 58 (2015) 418-425.

[15] Gaw, S.K., Wilkins, A.L., Kim, N.D., Palmer, G.T., Robinson, P., Trace element and $\mathrm{DDDT}$ concentrations in horticultural soils from The Tasman, Waikato and Auckland Regions of New Zealand, Science of The Total Environment, 355 (2006) 31-47.

[16] Al-Bachir, M., Sarhil, A., Al-Haddad, Th., Trace elements measurement in apricot (Prunus ArmeniacaL.) seeds by neutron activation analysis, Journal of Biotechnology and Biomedical Science, 1(3) (2018) 1-10.

[17] Saracoglu S., Tuzen M., Soylak M., Evaluation of trace element contents of dried apricot samples from Turkey, J. Hazard. Mater., 167 (2009) 647652.

[18] Mehari T.F., Greene, L., Duncan, A.L., Fakayode, S.O., Trace and macro elements concentrations in selected fresh fruits, vegetables, herbs, and processed foods in North Carolina, USA. J. Environ. Prot., 6 (2015) 573-583.

[19] Gergely A., Papp N., Banyai E.S., Hegedus A., Rabai M. et al., Assessment and examination of mineral elements in apricot (Prunus armeniaca L.) cultivars: A special attention to selenium and other essential elements, Eur. Chem. Bull., 3(8) (2014) 760-762.

[20] Zhanbin, L., Qinling, Z., Peng, L., Distribution characteristics of available trace elements in soil from a reclaimed land in a mining area of north 
Shaanxi, China, International Soil and Water Conservation Research, 1 (2013) 65-75.

[21] Yang, H., Wang, F., Yu, J., Huang, K., Zhang, H., Fu, Z., An improved weighted index for the assessment of heavy metal pollution in soils in Zhejiang, China, Environmental Research, 192 (2021) 110246.
[22] Yuan, X., Xue, N., Han, Z., A meta-analysis of heavy metals pollution in farmland and urban soils in China over the past 20 years, Journal of Environmental Sciences, 101 (2021) 217-226.

[23] Anonymous Regulation of setting maximum levels for certain contaminants in foodstuffs, Official Gazette, Iss: 24908 (2002). 